\title{
Analysis of the Effect of Governance and Research and Development on Probability of Default
}

\author{
Ani Nuraini ${ }^{1}$, Farah Margaretha Leon ${ }^{2}$, Bahtiar Usman ${ }^{3}$ \\ ${ }^{1}$ Economics Doctoral Program Students, Faculty of Economics and Business, Trisakti \\ University, Jakarta, Indonesia \\ ${ }^{2,3}$ Faculty of Economics and Business, Trisakti University, Jakarta, Indonesia \\ Email: ani@urindo.ac.id
}

\begin{abstract}
Research on the probability of default is always very interesting because it is related to the goals of companies that want to live on, this study aims to examine and analyze which variables are important in this study consisting of the audit committee and managerial ownership who are members of governance, as well as the $R$ \& $D$ variables. In influencing the probability of default either directly or indirectly by using the mediating variable Current Ratio estimated results (CRh), to predict the probability of default. This study uses Multiple Discriminant Analysis (MDA) in determining the value of the default probability, while the estimation analysis uses two-stage regression. The regression estimation results conclude that the governance variable on the audit committee has no direct effect on the probability of default, while the CRh mediation becomes significant. The managerial ownership variable which is part of the governance variable has a significant effect both directly and indirectly through $\mathrm{CRh}$ mediation, as well as the $R \& D$ variable which also has a significant effect on the probability of default either directly or indirectly. This study produces a model in which $\mathrm{CRh}$ as a mediator can signal the probability of default on non-financial variables such as governance and R\&D. The results of this study contribute to early detection of the probability of default of any non-financial variables that affect both governance and R\&D. This model was developed to anticipate the occurrence of bankruptcy by detecting the probability of default by using non-financial variables with $\mathrm{CRh}$ as mediation which is supported by model tests with Hosmer-Lemeshow and ROC.
\end{abstract}

Keywords: Default probability, Governance, $R \& D, C R h$.

\section{A. INTRODUCTION}

Failure can occur in every company, many large companies both in the world and in Indonesia have failed. These companies include as follows: Enron in 2001, WordCom in 2002, Lehman Brothers in 2008 and many more, while in Indonesia companies that went bankrupt in the 2016-2019 period included Nyonya Meneer, Sariwangi, Royal Standard, Duniatex and Krakatau Steel (Sari, 2017). The global crisis in 2008, impacted the manufacturing industry in Indonesia, especially products needed by the global market in the fourth quarter whose growth slowed down including the textile, leather goods and footwear industry, paper and printed goods industry, basic metal industry, iron and steel, machinery and equipment (Pemerintah, 2008).

Companies that experience a decrease in cash flow need to be watched out for and declared a failure if they cannot fulfill their obligations in both the short and long term. Good governance is very necessary in overcoming company defaults, the 
commitment of the audit committee and managers are one of the efforts to save the company from the probability of default (Hilaliya \& Margaretha, 2017). Improvements in company performance can be improved through the implementation of good governance, which includes policies on the transparency, ethical integrity, responsibility, accountability, independence and justice (Djohanputro, 2012). Corporate governance is an important variable in the performance of companies in the non-financial sector because governance involves human resources in it as a determinant of the good running of the company, so that effective governance in a company can increase investor confidence in the country's economy (Ciampi, 2015).

Technological advances need to be balanced with new innovations, especially in the current era of competition if companies want to live on. Businesses experience a cycle of ups and downs, for that before the business has decreased until it reaches negative cash flow which will result in default, the company needs to come up with new innovations. New innovations in a company can be generated from the existence of research and development $(R \& D)$, for this reason companies need to make efforts to allocate funds to finance $R \& D$ in order to find the level of effectiveness in their business in competition. $R$ \& $D$ is generally financed using debt, for this reason there must be good liquidity management so that companies avoid the probability of default. The company's response to change in investment spending in $\mathrm{R} \& \mathrm{D}$ is determined after the leverage reaches a certain amount, because the company will become more risky, considering that the probability of default will be much (Bragoli, Daniela; Cortelezzi, Flavia; Giannoccolo, Pierpaolo; Marseguerra, 2019).

The liquidity of a company must always be maintained, so that the company can show its good performance to share holders and stakeholders. Good liquidity management is supported by effective governance within a company that will result in good performance so that the company avoids the probability of default. The occurrence of defaults in a company begins with decreased cash inflows and eventually becomes negative, this is a problem for all companies that is very avoided, for that it is necessary to detect early in a company which factors are important which become the company's attention to anticipate the occurrence of the probability of default. $\mathrm{CR}$ is one of the financial ratios that provides accurate predictions of bankruptcy using the principal component analysis method (Chen, 2011).

This study aims to test which variables are important to determine the probability of default. In this study, the variables used to detect the probability of default are governance consisting of the audit committee and managerial ownership, as well as the $R \& D$ variables which are rarely studied in cases of default probability. The test was carried out by utilizing the current ratio variable to mediate non-financial variables consisting of governance and $R \& D$, this analysis will use two-stage regression, namely multiple regressions and logistic regressions with panel data. 


\section{B. LITERATURE REVIEW AND HYPOTHESES DEVELOPMENT}

Financial difficulties are a long process and go through a cycle in the form of stages that describe the company's financial condition leading to bankruptcy but not at once followed by the death of a company. Bankruptcy in a company can occur when a company cannot maintain its cash flow for a certain period (Wruck, 1990). Bankruptcy prediction dates back to the early 20th century, namely in 1932, when Fitzpatrick used an economic index to describe the predictive ability of a business's default. Subsequent research is to compare financial ratios and groupings of failed and non-failing companies (Beaver, 1966). Bankruptcy predictions were found by discriminant analysis which produced a Z-score (Altman, 1968). The bankruptcy performance of a company is assessed from a ratio analysis by calculating the average of various ratios such as cash flow to total debt, net income to total assets, working capital to total assets, in the ten years before bankruptcy (Li \& Wang, 2018).

Failed business firms have been defined in many ways in an attempt to describe the formal processes that firms face to categorize economic problems. The four general terms commonly found in the literature are failure, insolvency, default, and bankruptcy, although these terms are sometimes used interchangeably, they clearly differ in their formal usage. Failure, by economic criteria, means that the realized rates of return on invested capital, with an allowance for consideration of risk, are significantly and consistently lower than the rates applicable to similar investments. Insolvency is another term that describes negative company performance and is generally used in a more technical way. Technical insolvency occurs when a company is unable to meet its current obligations, this indicates a lack of liquidity according to Walter (Altman, Edward I. ; Hotchkiss, 2006).

Bankruptcy will shift share ownership from shareholders to lenders without changing the amount of value of all investors, in a perfect market (Berk, Jonathan ; DeMarzo, 2014). Company failure does not simultaneously affect bankruptcy, but is only a trigger for its negative consequences, the higher the cash flow volatility, the higher the probability of bankruptcy (Damodaran, 2015). Bankrupt companies have significantly higher levels of external debt and bank loans (Martin, Pospisil ; Jiri, 2019).

Non-financial information on governance variables has a higher predictive ability than financial information in emerging markets, so that both emerging and mature markets must take advantage of the combined predictive ability of integrated information because it can provide increased work effectiveness in predicting defaults (Fernando, Jayasurya Mahapatabendige Ruwani; Li, Leon; Hou, 2019). Research on the relationship between governance and financial performance, with independent variables consisting of board size, CEO duality, independent directors, ownership concentration, local investment ownership, foreign ownership, and leverage, and company size as a control variable by comparing family and nonfamily firms. From the results of statistical calculations, it is found that all independent variables a significant positive on company performance (Tobin's Q), Tobin's Q produces a negative effect on family firms (Saidat et al., 2019). In line with 
the research results, namely financial disclosure, board size, independent board, board ownership, independent audit committee and violation reporting policies have a positive effect on the company's financial performance (Kalyani, Sushil ; Mathur, 2019).

Agree with previous research which states that the corporate governance system has a significant effect on financial performance (Kumari \& Pattanayak, 2017). The results of the same study conclude that governance has a significant effect on prediction of default (Fernando et al., 2018). Another test says that the audit committee has a significant negative effect on the probability of financial distress (Luqman, Rabia; Ul et al., 2018), the same result is that the audit committee has a negative effect on default (Lakshan, A.M.I.; Wijekoon, 2012). Based on this description, the following hypothesis is formulated:

H1a : The Audit Committee on governance affects the probability of default

$\mathrm{H} 1 \mathrm{~b}$ : Managerial ownership in governance affects the probability of default

$\mathrm{H} 2 \mathrm{a}$ : The Audit Committee on governance affects the default probability mediated the Current Ratio.

$\mathrm{H} 2 \mathrm{~b}$ : Managerial ownership in governance affects the probability of default being mediated the Current Ratio

The development of science and technology will lead to new innovations, so those companies are required to always innovate in today's increasingly fierce competition. Investments made in R \& D are an innovative step either by companies or in a country in producing new products and processes, said the Main Science and Technology Indicators Database. R \& D is indispensable for companies to create innovation, so managers need to make strategies to determine whether the company will innovate by expecting high income and high risk (Liang \& Mo, 2017). Other research results suggest that investment in research and development have a positive influence on company performance (Li, Huajing; Tang, 2017). The study by examining the effect of $\mathrm{R} \& \mathrm{D}$ expenditures on company performance resulted that $\mathrm{R}$ \& D spending was not significant in influencing company performance, in this case ROA (Buchdadi et al., 2018). Most companies finance R \& D from debt, for that there needs to be a test of its effect on the probability of default, tests that have been carried out have shown that $R \& D$ is proven to have a significant effect on the probability of default (Cherkasova \& Kurlyanova, 2019). The results of this study provided room for $\mathrm{R} \& \mathrm{D}$ as an important variable to research, so the hypothesis is determined as follows:

H3a: R \& D affects Default Probability

H3b: R \& D affects Default Probability mediated the Current Ratio

This conceptual framework will describe more clearly the relationship between variables, where the audit committee variable and managerial ownership in governance and the $\mathrm{R} \& \mathrm{D}$ variable effect the probability of default through the current ratio as the mediating variable. 


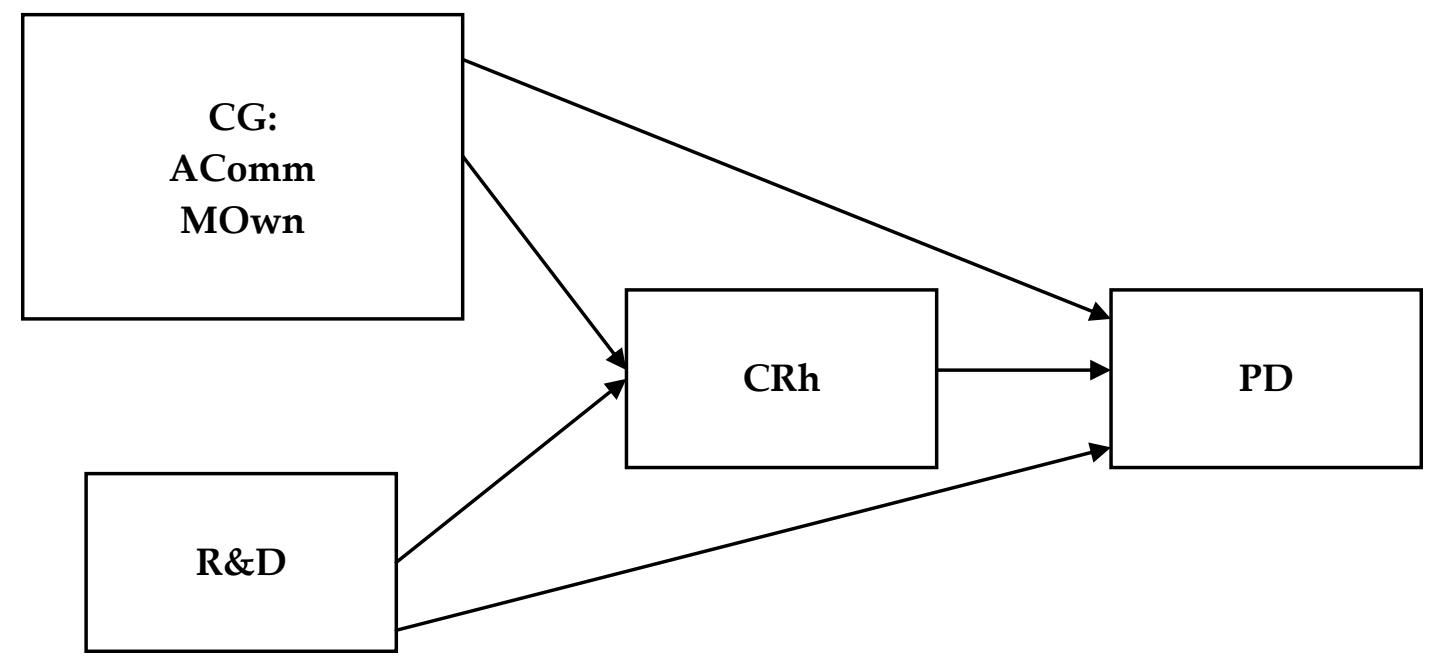

Figure 1 Concept Framework

\section{METHOD}

This study analyzes the influence between variables using mediating variables, which is carried out through two stages of regression, the first is multiple linear regression and the second is logistic regression. The data used his on manufacturing companies in Indonesia that have R\&D expenditure data in the 20092018 period and are listed on the Indonesia Stock Exchange which consists of 19 companies, resulting in 190 observational data.

\section{Panel Multiple Linear Regression}

The estimation results in the panel data regression will produce different intercept and slope coefficients for each company and time period (Widarjono, 2016). The resulting model structure consists of common effect, fixed effect and random effect, using two estimator methods consisting of the least square dummy variable and generalized least square (Ekananda, 2019), with the following main models: $\mathrm{Y}_{\mathrm{it}}=\beta_{0 \mathrm{it}}+\beta_{1} X_{\mathrm{it}}+\beta_{2} X_{\mathrm{it}}+\beta_{3} \mathrm{X}_{\mathrm{it}}+\cdots \ldots \ldots \ldots+€_{\mathrm{it}}$

In the fixed effect model, it is shown by the diversity of individuals, which is shown a different intercept $\beta_{01 \mathrm{t}} \neq \beta_{02 \mathrm{t}} \neq \beta_{03 \mathrm{t}} \neq \cdots \cdots \ldots \neq \beta_{0 \mathrm{i}}$ dan $\beta_{1 \mathrm{t}}=\beta_{2 \mathrm{t}}=\beta_{3 \mathrm{t}}=\ldots \ldots \ldots=\beta_{3 \mathrm{t}}$ while the random effect model is a model that pays attention to the diversity of the independent variables according to the individual and pays attention to different impacts for each individual, namely $\hat{\mathrm{a}}_{01 \mathrm{t}} \neq \beta_{02 \mathrm{t}} \neq \beta_{03 \mathrm{t}} \neq \cdots \cdots \cdots \neq \beta_{0 \mathrm{i}}$ dan $\beta_{1 \mathrm{t}} \neq \beta_{2 \mathrm{t}} \neq \beta_{3 \mathrm{t}} \neq$ $\ldots \ldots \ldots \neq \beta_{3 t}($ Ekananda, 2019)

\section{Logit Panel Regression}

The logistic model is a model in which the dependent variable undergoes a transformation into probability, namely $X \beta$ becomes a value of 0 to 1 . The form of the logistic equation is as follows (Latan, 2014): 
$\frac{P i}{1-P i}=e^{\mathrm{xi} \beta}$

(2)

So:

$\operatorname{Ln}\left[\frac{P i}{1-P i}\right]=\mathrm{z}=\mathrm{X} \beta=\mathrm{b}_{1} \mathrm{X}_{1}+\mathrm{b}_{2} \mathrm{X}_{2}+\ldots$

(3)

The logistic regression estimation results produce an equation model with regression coefficients that represent logit predictions, while the odds ratio on the logistic regression results is a measure of the effect size in logistic regression, which means that if a value above 1.0 indicates a positive effect and a value below 1.0 indicates a negative effect.

\section{Empirical Models}

This study examines how effective governance (AComm \& MOwn) and R\&D are in influencing the probability of default (PD) with CR mediation, so the following model is developed:

Stage I: The regression equation of panel data:

$C R=\boldsymbol{\beta}_{0}+\boldsymbol{\beta}_{1} A C o m m R+\boldsymbol{\beta}_{2} M O w n+\boldsymbol{\beta}_{3} R D \ldots \ldots+€_{i t}$

Stage II: Logistic regression equation:

$\frac{P i}{1-P i}=\mathrm{PD}={ }_{0}+\boldsymbol{\beta}_{1} C R h+\boldsymbol{\beta}_{2} A \operatorname{Comm} R+\boldsymbol{\beta}_{3} M O w n+\boldsymbol{\beta}_{4} R D \ldots \ldots+€_{\mathrm{it}}$

Equation (4) above is a panel data regression to obtain the CRh estimation results from the independent variables, namely the audit committee, managerial ownership and R \& D, which is then used as a mediation in equation (5), so that it will produce the PD value for each variable independent of either direct or indirect influence.

\section{Prediction Evaluation Methods}

Measurement and evaluation of panel data model predictions using the best model selection using the Chow test, Hausman test and Lagrange Multiplier test in the first regression stage, then determine the level of significance with prob value $\alpha<$ 0.05. The logistic regression model in the second stage uses the Pseudo $\mathrm{R}^{2}$ value to measure the fit of the model, which is an explanation of the independent variable variants of the dependent variable (Latan, 2014). Another fit test model used by the Hosmer and Lemeshow test is to group based on the value of the probability estimate. This test is proportionally reduced in the absolute value of the measured log-likelihood and is also measured by how much bad fit affects the estimation results of the variable predictors. A good $\mathrm{R}^{2} \mathrm{~L}$ value is indicated by Prob value $\alpha>$ 0.05 , which means that the model is fit or there is no miss specification, with a sample record < 400 (Hosmer et al., 2013), the same test can be done with the 
Pearson test. The ROC curve which provides an evaluation of the cut-off point boundary, comparing between sensitivity versus 1-specification, the ROC equivalent is a plot of the mean of true positives (sensitivity) and of mean of false positives (1specification) (Hosmer et al., 2013).

\section{Measurements of Variables}

To get a clearer picture of the variables required measurement, for that each variable is measured as shown in Table 1:

Table 1 Variable Definitions

\begin{tabular}{|c|c|}
\hline Variables & Definition \\
\hline $\begin{array}{l}\text { Corporate Governance: } \\
\text { Audit Committee (AComm) } \\
\text { Managerial Ownership (MOwn) }\end{array}$ & $\begin{array}{l}\text { AComm }=\frac{\text { number of members of the audit committee }}{\text { the number of commissioners }} \\
\text { MOwn }=\text { The total shares owned by management } \\
\text { Number of shares outstanding at the end of the year }\end{array}$ \\
\hline Research \& Development (R\&D) & $R \& D \quad=R \& D$ Investment Expenditure \\
\hline Current Ratio (CR) & $\mathrm{CR}=\frac{\text { Current asset }}{\text { Current liabilities }}$ \\
\hline Probability of Default & $\begin{array}{l}\text { Calculation results with discriminant analysis obtained } \\
\text { results } \check{D}=-3,806+9,155 X_{4} \text {, by criteria } \check{D} \geq-0,22593=1 \\
\text { (non-default) dan } \check{D}<-0,22593=0 \text { (default) }\end{array}$ \\
\hline
\end{tabular}

\section{Descriptive Data}

The measurement of the probability of default starts from bankruptcy calculated from financial ratios by Beaver (1966). It is important to maintain company performance and even improve it for the better, so it is important to detect earlier financial difficulties in order to avoid default. (James, 1995) found that many firms increased their investment spending only very slightly in the first two years after debt restructuring. (Hotchkiss, 1995) show that in each the one first five years after emerging from bankruptcy, between $35 \%$ and $41 \%$ of all firms had negative operating income. The dependent variable Default Probability in this study produces numbers 1 and 0 which are calculated using Multiple Discriminant Analysis (MDA), number 1 mean non-default and number 0 means default with details of the default number of 75 observations and non-default numbers of 115 observations. Numbers 0 and 1 are obtained using ZETA $^{\text {TM* }}{ }^{*}$ analysis, which consists of 7 variables selected using MDA, the seven variables consist of ROA $\left(X_{1}\right)$, income stability $\left(X_{2}\right)$, debt $\left(X_{3}\right)$, cumulative profit $\left(X_{4}\right)$, liquidity $\left(X_{5}\right)$, Capitalization $\left(X_{6}\right)$, and Size $\left(X_{7}\right)$ (Altman ${ }^{* *}$, Edward I.3; Haldeman, Robert G.; Narayanan, 1977).

The Audit Committee (AComm) variable in the calculation results gives an average value of 0.7020745 with a standard deviation of 0.2778017 , the minimum value of 0.2727273 is owned by Astra Autopart Tbk in 2013, while the maximum 
value of 1.5 is owned by Champiom Pacific Indonesia Tbk (2015-2016) and Merck Tbk 2018. AComm variable data is determined by calculating the number of audit committee members divided by the number of commissioners in the company. The variable Managerial Ownership (MOwn) in the calculation results gives an average value of 0.0898125 with a standard deviation of 0.135339 , a minimum value of $5.06 \mathrm{e}-$ 06 is owned by PT. Indoacitama Tbk (2009-2010), while the maximum value is 0.5177726 owned by PT. Indo Acidatama (2017-2018). MOwn variable data is calculated from the total shares owned by management divided by the number of shares outstanding at the end of the year.

The Research \& Development (RD) variable in the calculation results gives an average value of 3.947229 with a standard deviation of 0.9540897 , the minimum value of 2.193125 is owned by PT. Ultrajaya Milk Industry and Trading Company Tbk, while the maximum value is 6,490359 owned by PT. Unilever Indonesia. RD variable data is determined as investment expenditure in the Research \& Development sector. The variable Current Ratio (CR) in the calculation results gives an average value of 3.094718 with a standard deviation of 1.755906 , the minimum value of 0.6056319 is owned by PT. Unilever Indonesia in 2016, while the maximum value is 9.344671 owned by PT. Lion Metal Works in 2012. CR data is calculated from the ratio between current assets to current debt (Zutter, Chad J. ; Smart, 2019).

\section{RESULT AND DISCUSSION}

Regression in the first stage based on the results of model selection is best to use a fixed effect model, this regression result produces a regression coefficient of the AComm, MOwn and $\mathrm{R} \& \mathrm{D}$ variables, to determine the estimation results on $\mathrm{CR}$ which will be used as a mediating variable against the default probability.

Table 2 Regression Results Stage I

\begin{tabular}{|l|c|c|c|}
\hline \multicolumn{1}{|c|}{ CR } & Coefficient & Std. Error & Prob. \\
\hline AComm & -1.2605 & 0.8754308 & 0.155 \\
MOwn & 1.058731 & 1.537554 & 0.494 \\
R\&D & $-1.29686^{*}$ & 0.3777206 & 0.001 \\
Constanta & 8.797709 & 1.577895 & 0 \\
\hline
\end{tabular}

*significant on $\alpha<0.05$

Source: researcher data processing results

The regression results in Table 2 conclude that $R \& D$ is significantly negative in influencing CR with a prob value. $\alpha<0.05$, whereas at AComm and MOwn it was not significant with prob. $\alpha>0.05$, the estimation results of the model are then used to estimate the CR which will be included in the second stage logistical regression model, although the AComm and MOwn variables are not significant but are still included in the model (Ekananda, 2019), so that the CR estimation results become CRh. 
Table 3 Estimation Results of Phase II Logistic Regression Coefficients:

\begin{tabular}{|l|c|c|c|}
\hline \multicolumn{1}{|c|}{ PD } & Coefficient & Std. Error & Prob. \\
\hline AComm & -2.658441 & 1.457866 & 0.068 \\
MOwn & 6.868506 & 2.448183 & 0.005 \\
R\&D & -.5726716 & .1457592 & 0.000 \\
CRh & -13.95586 & 4.006487 & 0.000 \\
Constanta & 13.06808 & 3.827994 & 0.001 \\
\hline
\end{tabular}

*significant on $\alpha<0.05$

Source: researcher data processing results

The results of the estimation calculations are in table 3. As a result of the logistic regression estimation, the results show that the AComm governance variable is not significant with prob. $\alpha>0.05$ while the MOwn has a significant positive effect with prob. $\alpha<0.05$. The $\mathrm{R} \& \mathrm{D}$ variable has a significant negative effect on the probability of default indicated by the probability value. $\alpha<0.05$. The CRh variable as a mediator has a significant negative effect in affecting the probability of default indicated by the probability value. $\alpha<0.05$, which means that the AComm, MOwn and $R \& D$ through $C R h$ variables have a significant negative effect in affecting the probability of default.

Table 4 Odds Ratio Regression Results

\begin{tabular}{|l|c|c|c|c|}
\hline \multicolumn{1}{|c|}{ PD } & Odds Ratio & Std. Error & $\mathbf{z}$ & Prob. \\
\hline AComm & .0700573 & .1021342 & -1.82 & 0.068 \\
MOwn & 961.511 & 2353.955 & 2.81 & 0.005 \\
R\&D & .5640166 & .0822106 & -3.93 & 0.000 \\
CRh & $8.69 \mathrm{e}-07$ & $3.48 \mathrm{e}-06$ & -3.48 & 0.000 \\
Constanta & 473583.4 & 1812874 & 3.41 & 0.001 \\
\hline
\end{tabular}

*significant on $\alpha<0.05$

Source: researcher data processing results

Odds ratio shows that the probability of default against non-default on the Acomm variable is not significant, at MOwn, which increases significantly the chance of default against non-default is 961,511 times, which increases in R \& D has a significant effect on decreasing the probability of default against non-default by 0.5640166 times. The increasing CRh has a significant effect on decreasing the probability of default against non-default by $8.69 \mathrm{e}-07$ times, which means that all variables consisting of AComm, MOwn and R\&D have the opportunity to reduce the probability of default against non-default with increased CRh mediation.

The model test in logistic regression is shown by:

Hosmer and Lemeshow test results

Number of groups $\quad=19$

Hosmer-Lemeshow chi2 (17) $=8.81$

Prob $>$ chi $^{2} \quad=0.9460$

A good $R_{L}^{2}$ value is indicated by prob. value $\alpha>0.05$, where the prob. $0.9460>$ 0.05 , this result shows that the model is fit and there is no misspecification (Latan, 2014). To find out the accuracy of the model in making classifications, it can be seen in table 5 below as a result of data processing: 
Table 5 Model classification

\begin{tabular}{|c|rc|c|}
\hline Classified & D & $\sim \mathrm{D}$ & Total \\
\hline+ & 15 & 4 & 19 \\
- & 7 & 57 & 64 \\
\hline Total & 22 & 61 & 83 \\
\hline
\end{tabular}

Source: researcher data processing results

Notes: $\mathrm{D}$ where $\mathrm{Y}=1$ and $\sim \mathrm{D}$ where $\mathrm{Y}=0$ for observational data

Based on table 5, the classification of the model can be seen that there are 15 correct defaults, this classification is carried out accurately on the probability model not less than 0.5 which is the cut-off value, and 57 is not the default, so that the correctly classified model is $15+57=72$ of 83 or $86.75 \%$. Table 5 also provides information about the sensitivity probability which is the presentation of observations with a probability value of $\geq 0.5$, namely 15 out of 22 or $68.18 \%$. Furthermore, the ROC curve in Figure 2. below describes the model's ability to measure likelihood discrimination between subjects, with a number below ROC = 0.8018 , according to the rule of thumb if $0.8 \leq \mathrm{ROC} \leq 0.9$, it is concluded that there is extraordinary discrimination (Hosmer et al., 2013).

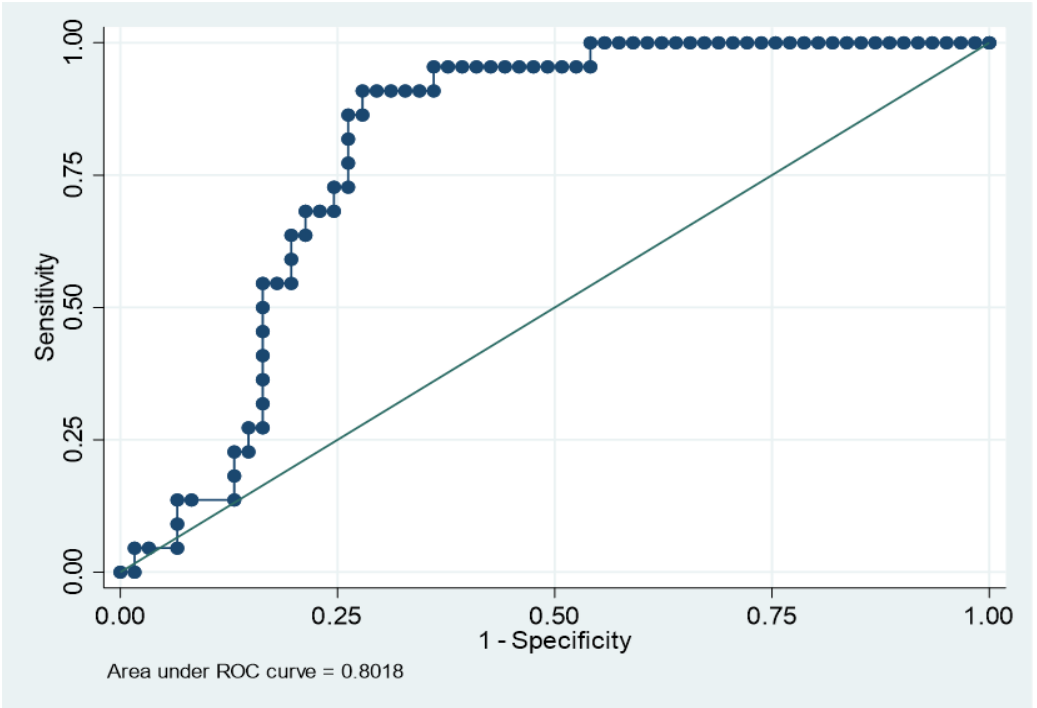

Figure 2 ROC Curve

The regression results in the first stage conclude that Acomm and MOwn are not significant to CR, this result is in line with previous research on the effect of governance on financial performance on CR is not significant (Suhadak et al., 2019), this is because from the data obtained, the average company is still relatively small in number of audit committees and not in accordance with the provisions of the Financial Services Authority Number: 55 / POJK.04.2015 regarding the minimum number of audit committees is $30 \%$, as well as managerial ownership has not contributed to liquidity management because there are still few companies in research data whose shares are owned by managers. The $R \& D$ variable has a significant negative effect in affecting CR, this is due to reduced cash as a result of spending on R\&D investment, in accordance with previous research which 
concluded that investment in $\mathrm{R} \& \mathrm{D}$ has a negative correlation to company profitability due to the influence of lag (You \& Meng, 2018).

Regression in the second stage concludes that almost all of the independent variables have a significant effect, except for the audit committee variable which has no significant effect on the probability of default. The managerial ownership variable has a positive effect and is likely to have a probability of default compared to nondefault, so the greater the composition of directors' ownership in stocks will have the opportunity for the probability of default, as previously stated that there is too little data on company managerial ownership in this study which happens to be found in companies that have probability of default. This result is supported by previous research which concludes that managerial ownership has a positive effect on financial difficulties (Widhiadnyana \& Dwi Ratnadi, 2019). The R\&D variable has a negative effect and is likely to have a decreased probability of default if there is an increase in $R \& D$ investment spending. Companies in Indonesia generally still use a small amount of debt to fund $R \& D$ investment, on average funding still uses their own funds because there is still relatively little allocation of funds for R\&D and the lack of R\&D expenditure data obtained from manufacturing companies in Indonesia. These results are in accordance with research which states that R\&D expenditures significantly reduce the probability of default (Cherkasova \& Kurlyanova, 2019).

The estimation results and default probability on the CRh variable as mediation with the CRh notation concludes that CRh has a significant negative effect and has the opportunity to reduce the probability of default against default if there is an increase in CRh, this is in accordance with the theory that if liquidity in a company increases, it will have an effect on decreasing the probability of default. The results of this study are supported by previous research which states that CR has a negative effect on financial distress (Platt, Harlan D. ; Platt, 2002), this result is also supported by other researchers that CR negatively affects the probability of default (Dance, Mesak; I Made, 2019). This mediation makes independent variables such as the audit committee which are not directly significant in influencing the default, to be significant in the CRh mediation.

\section{E. CONCLUSION}

The results of this study are inseparable from the aim of generally wanting to know whether the variables under study can be used to make predictions about the default probability either directly or indirectly by using the CRh mediating variable. Specifically, this study aims to examine the hypothesis of the effect of governance variables consisting of audit committee and managerial ownership on the probability of default either directly or mediated by CRh, as well as the influence of the $\mathrm{R} \& \mathrm{D}$ variable on the probability of default either directly or indirectly through $\mathrm{CRh}$ as mediation. $\mathrm{R} \& \mathrm{D}$ is a variable that is accommodated as a variable that produces innovation in the era of technological development and is rarely used for prediction of default, where this variable is usually funded from debt. 
This research was conducted with two-stage regression, first using panel data regression and in the second stage using logistic regression. The first stage of governance and R\&D variables is regressed against CR which is then processed and produces an estimate of CRh which is used as a mediation in logistic regression as an independent variable along with governance and R\&D on the probability of default. The regression estimation results conclude that the governance variable on the audit committee has no direct effect on the probability of default, while the CRh mediation becomes significant. The managerial ownership variable which is part of the governance variable has a significant effect both directly and indirectly through CRh mediation, as well as the R\&D variable which also has a significant effect on the probability of default either directly or indirectly.

Model testing in this study is supported by the results of the HosmerLemeshow test with a prob. value $0.9460>0.05$, which indicates that the model is fit, and the classification table provides information about the sensitivity probability which is the presentation of the observation with a probability value $\geq 0.5$, which is 15 out of 22 or $68.18 \%$ correctly classified as default. The results of the ROC curve can explain the ability of the model in measuring likelihood discrimination between subjects, with a number below $\mathrm{ROC}=0.8018$, according to the rule of thumb if $0.8 \leq$ $\mathrm{ROC} \leq 0.9$ it is concluded that there is extraordinary discrimination.

The data on the research variables are still very few and not continuous considering that in Indonesia not all companies in the manufacturing industry fulfill the regulatory criteria proportionally on the audit committee and managerial ownership, while in the $R \& D$ data not all companies include $R \& D$ investment expenditures in their financial reports because they are considered having a lack of funds which is used for $R \& D$ so that it does not use debt specifically in $R \& D$ financing which affects the capital structure. The results of this study contribute to the company to always pay attention to, evaluate and maintain its cash flow to detect the probability of default any non-financial variables that affect both governance and $R \& D$ must ultimately refer to $C R$, where there are signs that $C R$ is unstable or even decreasing (Damodaran, 2015), companies must be aware of the probability of default while maintaining cash flow to remain stable so that companies survive and avoid financial difficulties to bankruptcy. Investors and shareholders are not too difficult to see the company's financial performance, only by paying attention to the trend of $\mathrm{CR}$ can immediately make decisions in investment policies, but there is nothing wrong with paying attention to other financial ratios that are no less important, which can provide an overview of the performance of a company whole.

Based on the results of this study, several further studies can be developed including by making comparisons between companies with different sectors so that it is known which sector companies are vulnerable to the probability of default, besides that, comparisons can also be made between countries. The mediating variable can be developed into several ratios as in previous researchers who used multiple ratios to detect default (Li \& Wang, 2018), but not a mediating variable. 


\section{REFERENCES}

1. Altman, Edward I. ; Hotchkiss, E. (2006). Corporate Credit Scoring-insolvency Risk Models. In Corporate Financial Distress and Bankruptcy. John Wiley \& Sons, Inc. https://doi.org/10.1002/9781118267806.ch11

2. Altman**, Edward I.; Haldeman, Robert G.; Narayanan, P. (1977). ZETATM analysis A new model to identify bankruptcy risk of corporations. Journal of Banking and Finance, 1(1), 29-54. https://doi.org/10.1016/0378-4266(77)90017-6

3. Altman, E. I. (1968). Financial Ratios, Discriminant Analysis and Prediction of Corporate Bankruptcy. The Journal of Finance, 23(4), 589-609.

4. Beaver, W. H. (1966). of Failure Financial Ratios as Predictors. Journal of Accounting Research, 4(1966), 71-111. http://www.jstor.org/stable/2490171

5. Berk, Jonathan; DeMarzo, P. (2014). Corporate Finance (D. Battista (ed.); 3rd ed.). Pearson.

6. Bragoli, Daniela; Cortelezzi, Flavia; Giannoccolo, Pierpaolo; Marseguerra, G. (2019). R\&D Investment timing, default and capital structure. Review of Quantitative Finance and Accounting, 0123456789. https://doi.org/10.1007/s11156019-00807-6

7. Buchdadi, A. D., Oktafianto, E., \& Mardiyati, U. (2018). Pengaruh R\&D Expenditure Terhadap Firm Performance Pada Perusahaan Yang Terdaftar Di Bei Periode 2003-2015. JRMSI - Jurnal Riset Manajemen Sains Indonesia, 9(2), 337351. https://doi.org/10.21009/jrmsi.009.2.09

8. Chen, M.-Y. (2011). Bankruptcy prediction in firms with statistical and intelligent techniques and a comparison of evolutionary computation approaches. Computers and Mathematics with Applications, 62(12), 4514-4524. https://doi.org/10.1016/j.camwa.2011.10.030

9. Cherkasova, V., \& Kurlyanova, A. (2019). Does corporate R\&D investment support to decrease of default probability of Asian firms? Borsa Istanbul Review, 19(4), 344-356. https://doi.org/10.1016/j.bir.2019.07.009

10. Ciampi, F. (2015). Corporate governance characteristics and default prediction modeling for small enterprises. An empirical analysis of Italian firms. Journal of Business Research, 68(5), 1012-1025. https://doi.org/10.1016/j.jbusres.2014.10.003

11. Damodaran, A. (2015). Applied Corporate Finance (J. Hollenbeck (ed.); 4th ed.). John Wiley \& Sons, Inc.

12. Dance, Mesak; I Made, S. (2019). Financial Ratio Analysis in Predicting Financial Conditions Distress in Indonesia Stock Exchange. Russian Journal of Agricultural and Socio-Economic Sciences, 86(2), 155-165. https://doi.org/10.18551/rjoas.201902.18

13. Djohanputro, B. (2012). Manajemen Risiko Korporat Terintegrasi (S. F. Manalu (ed.)). PPM.

14. Ekananda, M. (2019). Ekonometrika Dasar (2nd ed.). Mitra Wacana Media.

15. Fernando, Jayasurya Mahapatabendige Ruwani; Li, Leon; Hou, G. (2019). Financial versus Non-Financial Information for Default Prediction: Evidence from Sri Lanka and the USA. Emerging Markets Finance and Trade, 00(00), 1-20. 
https://doi.org/10.1080/1540496X.2018.1545644

16. Fernando, J. M. R., Li, L., \& Hou, Y. (Greg). (2018). Corporate governance and default prediction: a reality test. Applied Economics, 51(24), 2669-2686. https://doi.org/10.1080/00036846.2018.1558351

17. Hilaliya, T., \& Margaretha, F. (2017). Peran Corporate Governance dalam Menurunkan Kebangkrutan pada Perusahaan di Indonesia. Jurnal Akuntansi, 21(3), 391. https://doi.org/10.24912/ja.v21i3.267

18. Hosmer, D. W., Lemeshow, S., \& Sturdivant, R. X. (2013). Applied Logistic Regression: Third Edition. In Applied Logistic Regression: Third Edition. https://doi.org/10.1002/9781118548387

19. Hotchkiss, E. S. (1995). Postbankruptcy Performance and Management Turnover. The Journal of Finance, L(1), 3-21. http://www.jstor.org/stable/2962304 Accessed:

20. James, C. (1995). The Society for Financial Studies When Do Banks Take Equity in Debt Restructurings? Author (s): Christopher James Source: The Review of Financial Studies, Vol. 8, No. 4 (Winter, 1995), pp. 1209-1234 Published by: Oxford University Press. Spo. 8(4), 1209-1234. http://www.jstor.org/stable/2962304 Accessed:

21. Kalyani, Sushil; Mathur, N. (2019). Does Corporate Governance Affect the Financial Performance and Quality of Financial Reporting of Companies? A Study on Selected Indian Companies. Business Governance and Society, 105-125. https://doi.org/https://doi.org/10.1007/978-3-319-94613-9_7

22. Kumari, P., \& Pattanayak, J. K. (2017). Linking earnings management practices and corporate governance system with the firm's financial performance A study of Indian commercial banks. Journal of Financial Crime, 24(2), 223-241. https://doi.org/10.1108/JFC-03-2016-0020

23. Lakshan, A.M.I.; Wijekoon, W. M. H. N. (2012). Corporate governance and corporate failure. Procedia; Economics and Finance, 2nd Annual International Conference on Accounting and Finance (AF 2012), 2, 191-198. https://doi.org/10.1016/S2212-5671(12)00079-2

24. Latan, H. (2014). Aplikasi Analisis Data Statistik untuk Ilmu Sosial Sains dengan STATA (Kesatu). Bandung: Alfabeta.

25. Li, Huajing; Tang, J. (2017). Technological human capital, firm innovativeness, and entrepreneurial success: the moderating role of seeking and receiving external funding. World Review of Entrepreneurship, Management and Sustainable Development, 13(1). https://doi.org/DOI: 10.1504/WREMSD.2017.080761

26. Li, Y., \& Wang, Y. (2018). Machine Learning Methods of Bankruptcy Prediction Using Accounting Ratios. Open Journal of Business and Management, 06(01), 1-20. https://doi.org/10.4236/ojbm.2018.61001

27. Liang, T., \& Mo, X. (2017). Research on the Relationship between Managerial Overconfidence and Corporate $\mathrm{R}$ \&amp; D Investment in the Context of Financing Constraints. Open Journal of Business and Management, 05(01), 22-33. https://doi.org/10.4236/ojbm.2017.51003

28. Luqman, Rabia; Ul, M., Tabasum, S., \& Khakwani, M. S. (2018). Probability of financial distress and proposed adoption of corporate governance structures: 
Evidence from Pakistan. Cogent Business $\mathcal{E}$ Management, 5(1), 1-14. https://doi.org/10.1080/23311975.2018.1492869

29. Martin, Pospisil; Jiri, S. (2019). Bankruptcy, Investment, and Financial Constraints. Working Paper, 8(5), 55.

30. Pemerintah, B. (2008). Menyelamatkan Industri dari Dampak Krisis (Issue 05). https:/www.bappenas.go.id/files/2413/5027/3724/bab-2handbook2009050509_20090518110628_1.pdf

31. Platt, Harlan D.; Platt, M. B. (2002). Predicting corporate financial distress: Reflections on choice-based sample bias. Journal of Economics and Finance, 26(2), 184-199.

32. Saidat, Z., Silva, M., \& Seaman, C. (2019). The relationship between corporate governance and financial performance: Evidence from Jordanian family and nonfamily firms. Journal of Family Business Management, 9(1), 54-78. https://doi.org/10.1108/JFBM-11-2017-0036

33. Sari, D. P. (2017). Ini Daftar Perusahaan Yang Pailit Sepanjang 2017. Bisnis.Com. https://kabar24.bisnis.com/read/20171228/16/721762/ini-daftar-perusahaan-yangpailit-sepanjang-2017

34. Suhadak, S., Mangesti Rahayu, S., \& Handayani, S. R. (2019). GCG, financial architecture on stock return, financial performance and corporate value. International Journal of Productivity and Performance Management. https://doi.org/10.1108/IJPPM-09-2017-0224

35. Widarjono, A. (2016). Ekonometrika Pengantar dan Aplikasinya (Keempat). UPP STIM YKPN.

36. Widhiadnyana, I. K., \& Dwi Ratnadi, N. M. (2019). The impact of managerial ownership, institutional ownership, proportion of independent commissioner, and intellectual capital on financial distress. Journal of Economics, Business $\mathcal{E}$ Accountancy Ventura, 21(3), 351. https://doi.org/10.14414/jebav.v21i3.1233

37. Wruck, K. H. (1990). Financial distress, reorganization, and organizational efficiency. Journal of Financial Economics, 27(2), 419-444. https://doi.org/10.1016/0304-405X(90)90063-6

38. You, H., \& Meng, Q. (2018). Research on the "Stickiness" Relationship between R \&amp; D and Profitablity of "Unicon" Company - Data Based on the AI Concept Stocks. Open Journal of Business and Management, 06(04), 938-943. https://doi.org/10.4236/ojbm.2018.64068

39. Zutter, Chad J.; Smart, S. B. (2019). Principles of Managerial Finance (C. Fenn (ed.); Fifteenth). Pearson. 